\title{
PENERAPAN METODE PEMBELAJARAN PERINGATAN DAN PEMBERIAN MOTIVASI TERHADAP PENINGKATAN MINAT BELAJAR BIDANG STUDI EKONOMI PADA MATERI POKOK KONSUMSI, TABUNGAN DAN INVESTASI PESERTA DIDIK KELAS X PON-PES MUHAMMADIYAH KHA.DAHLAN SIPIROK TAHUN PELAJARAN 2016-2017
}

\author{
${ }^{(1)}$ Zainab Rambe dan ${ }^{(2)}$ Benny Sofyan Samosir \\ ${ }^{(1)}$ Mahasiswa FKIP Universitas Muhammadiyah Tapanuli Selatan \\ ${ }^{(2)}$ Dosen FKIP Univeristas Muhammadiyah Tapanuli Selatan
}

\begin{abstract}
Abstrak
Jenis penelitian yang digunakan dalam penelitian ini adalah penilitian asosiatif yang bertujuan untuk mengetahui hubungan antara dua variabel atau lebih yang kebetulan munculnya bersama. Tekhnik pengumpulan data dilakukan dengan penyebaran angket untuk metode pembelajaran peringatan dan pemberian motivasi. Tes untuk peningkatan minat. Statistik yang digunakan untuk menguji hipotesis digunakan rumus korelasi product moment ganda :

$$
r_{y x 1 x 2}=\sqrt{\frac{r_{y x 1+}^{2} r_{y x 2-2 r_{y x 1} r_{y x 2} r_{x 1 x 2}}^{2}}{r_{x 1 x 2}^{2}}}
$$

Berdasarkan analisis data yang dilakukan melalui korelasi product moment ganda maka diperoleh nilai $r$ hitung 0,963dan nilai $r_{\text {tabel }}$ 0,361 taraf kesalahan 5\% dengan $N=30$. Dari nilai tersebut dapat dilihat bahwa rhitung lebih besar dari yaitu0,963>0,361 dapat dikatakan bahwa Ada Penerapan Metode Pembelajaran Peringatan Dan Pemberian Motivasi Terhadap Peningkatan Minat Belajar Bidang Studi Ekonomi Pada Materi Pokok Konsumsi, Tabungan Dan Investasi Peserta Didik Kelas X Pon-Pes Muhammadiyah KHA. Dahlan Sipirok Tahun Pelajaran 2016-2017.
\end{abstract}

Kata Kunci: Metode Pembelajaran, Minat Belajar, Konsumsi

\section{Pendahuluan}

Pendidikan merupakan hal yang sangat penting dan tidak bisa lepas dari kehidupan ummat manusia untuk memperta hankan keberlangsungan eksistensi.
Pendidikan dimaknai dan difahami sebagai sebuah wahana untuk menyalurkan ilmu pengetahuan,alat pembentuk watak, alat pelatihan keterampilan, alat mengasah otak,serta media untuk meningkatkan 
keterampilan kerja.Pendidikan merupakan salah satu bentuk perwujudan kebudayaan manusia yang dinamis dan sarat perkembangan. Oleh karena itu,perubahan atau perkembangan pendidikan adalah hal yang memang seharusnya terjadi sejalan dengan perubahan budaya dan kehidupan.Perubahan dalam pendidikan perlu terus menerus dilakukan sebagai antisipasi kepentingan masa depan.

Menjadi bangsa yang maju tentu merupakan cita-cita yang ingin dicapai oleh negara di dunia. Sudah menjadi suatu kebenaran umum bahwa maju mundurnya suatu negara dipengaruhi oleh faktor pendidikan yang tentunya akan

"Terwujudnya sistem pendidikan sebagai pranata sosial yang kuat dan berwibawa untuk memberdayakan semua Negara berkembang menjadi manusia yang berkualitas sehingga mampu dan proaktif menjawab tantangan zaman yang selalu berubah

Pendapat ini memandang pendidikan bukan hanya sebagai pemberian informasi pengetahuan dan pembentukan keterampilan melainkan lebih luas dari itu, meliputi usaha yang sistematisuntuk membentuk dan meningkatkan kualitas kepribadian dengan karakteristik yang kreatif, mandiri, tanggung jawab,ulet dan tekun.

Visi pendidikan yang disebut di atas sering tidak tercapai dengan maksimal khususnya pada pembelajaran ekonomi,padahal begitu besar peran ekonomi dalam kehidupan.
Ekonomi merupakan ilmu pengetahuan yang erat hubungannya dengan kehidupan sehari-hari dalam memilih dan menciptakan kemakmuran. Konsep-konsep ekonomi akan sangat membantu dalam menyelesaikan masalah yang berkaitan dengan perekonomian suatu negara.

Dalam mempelajari ekonomi, anda akan diarahkan untukmencari tahu tentang perkonomian dan berbagai fakta lainnya.Pada proses tersebut anda diharapkan mejadi pribadi yang jujur, objektif, ulet,dan bekerja sama. Dengan demikian anda dapat menerapkan ilmu ekonomi dalam kehidupan dan menyelesaikan masalah.

Suatu proses belajar mengajar pemilihan metode mengajar yang tepat merupakan langkah yang turut menentukan keberhasilan proses belajar. Sebab salah satu komponen pengajaran yang menentukan keterampilan tujuan pengajaran adalah ketepatan pemilihan metode pengajaran,karena itu guru harus memilih, menetapkan dan menggunakan metode yang sesuai dengan materi pokok,situasi dan kondisi yang ada,setiap metode mengajar memiliki keunggulandan kelemahan masing-masing.Untuk menutupi kelemahan tersebut harus diimbangi dengan metode yang lain untuk menghasilkan proses belajar mengajar yang lebih maksimal tentunya dengan perencanaan yang matang.

Masalah lain adalah pembelajaran masih kurang diminati oleh peserta didik, ketertarikan dalam pembelajaran dan kurang memperhatikan ketuntasan belajar secara individual, karena guru lebih banyak menempatkan peserta didik sebagai objek 
dan bukan sebagai subjek didik. Disamping itu juga banyak terjadi tingkah laku peserta didik yang dapat menurunkan minat belajar peserta didik. Sebagai contoh yaitu peserta didik lebih mementingkan bidang studi yang ditonjolkan disekolah, dan ada banyak kegiatan yang harus diselesaikan sebagai rutinitas sehari-hari peserta didik, sehingga peserta didik hanya terfokus pada bidang studi tersebut. Ketika belajar peserta didik lebih banyak mengerjakan tugas bidang studi lain,karena banyak tugas yang diberikan oleh guru bidang studi lainnya. Disini gurunya juga kurang memberikan kesempatan kepada peserta didik dalam berbagai mata pelajaran,untuk mengembangkan kemampuan berfikir dan semangat dalam belajarnya.

Disamping metode belajar yang kurang efektif,peserta didik banyak yang melanggar peraturan di sekolahnya dikarenakan kurangnya minat dan ketertarikan belajarnya dengan metode yang dibawakan oleh guru. Jadi, untuk itu peserta didik perlu diberi peringatan atas kesalahan yang dilakukannya dan akan diberikan motivasi oleh guru untuk perubahan akan kesalahan dan minat belajar peserta didik tersebut.

Hasil wawancara yang dilakukan tanggl 10 oktober2016 dengan bapak Riduan Anugrah Art,S.Pdselaku guru bidang studi ekonomi dalam proses mengajar dia hanya menggunakan metode mencatat materi dan dilanjutkan dengan penjelasan materi,dan memberikan soal latihan,sementara peserta didik hanya mendengar dan mencatat materi sehingga peserta didik tidak termotivasi untuk belajar.
Berdasarkan hasil tes diagnostik yang dilaksanakan kepada peserta didik kelas $\mathrm{X}$ Pon-pes Muhammadiyah KHA.Dahlan Sipirok pada materi pokok konsumsi, tabungan dan investasi. Dimana 30 peserta didik yang mengikuti tes diperoleh hanya 7 atau $23,3 \%$ peserta didik yang tuntas dan 23 atau $76,6 \%$ peserta didik yang tidak tuntas,sedangkan nilai rata- rata yang diperoleh peserta didik belum memenuhi kriteria ketuntasan minimal(KKM) yang ditetapkan oleh sekolah yaitu 72. Hal tersebut menunjukkan bahwa prestasi belajar ekonomi peserta didik pada materi pokok konsumsi,tabungan dan investasi dalam menjawab soal masih rendah. Penyebabnya adalah minat belajar peserta didik terhadap ekonomi masih rendah karena tidak adanya ketertarikan belajar sehingga peserta didik kurang aktif dalam proses pembelajaran.Penggunaan metode pembelajaran kurang bervariasi yang dapat mengakibatkan peserta didik merasa jenuh dan tidak termotivasi pada saat mengikuti pelajaran sehingga banyak peserta didik melanggar peraturandi sekolah, bahkan banyak kesalahan-kesalahan yang dilakukan oleh peserta didik. Selain itu dalam belajar sebagian besar waktu pembelajaran yang digunakan oleh guru hanya mencacat materi sehingga hubungan peserta didik dengan guru tidak terlibat sewaktu pelajaran berlangsung,interaksi belajar rendah.

\begin{tabular}{l}
\multicolumn{3}{c}{ Berdasarkan uraian diatas,maka } \\
peneliti tertarik melakukan $\begin{array}{r}\text { penelitian } \\
\text { dengan judul : Penerapan }\end{array}$ Metode \\
Pembelajaran Peringatan Dan Pemberian \\
Motivasi Terhadap Peningkatan Minat
\end{tabular}

Berdasarkan uraian diatas,maka peneliti tertarik melakukan penelitian Pembelajaran Peringatan Dan Pemberian Motivasi Terhadap Peningkatan Minat 
Belajar Bidang Studi Ekonomi Pada Materi Pokok Konsumsi, Tabungan Dan Investasi Peserta Didik Kelas X Pon-Pes Muhammadiyah Kha.Dahlan Sipirok Tahun Pelajaran 2016-2017.

\section{Metode Penelitian}

Tekhnik pengumpulan data yang dipergunakan adalah sebagai berikut :

1. Penelitian Kepustakaan

Penelitian kepustakaan ini penulis berusaha mengumpulkan data yang tertulis yang tertulis yang bersumber dari bukubuku literature dan sumber-sumber tertulis lainnya yang terkait dalam masalah dalam penelitian ini.

2. Penelitian Lapangan

Penelitian lapangan ini penulis telah mengadakan penelitian di lapangan,dalam hal ini adalah peserta didik dikelas X PonPes Muhammadiyah KHA. Dahlan Sipirok Tahun Pelajaran 2016/2017.

Prosedur penelitian merupakan langkah yang harus di tempuh dalam penelitian ini. Adapun prosedur atau langkah-langkahnya adalah :

1. Perencanaan

a. Suatu kegiatan yang telah direncanakan atas inisiatif peneliti, sehingga menumbuhkan segala sesuatu yang dianggap perlu dan pelaksanaan sudah diperkirakan.

b. Persiapan yang dilakukan untuk pelaksanaan penelitian dengan membuat rencana pelaksanaannya yang disesuaikan dengan kondisi dimana penelitian diadakan dan sekaligus memenuhi terhadap kepentingan yang ada hubungan secara langsung.
2. Pelaksanaan

Penelitian ini dilaksanakan sesuai dengan pokok permasalahan yang akan diteliti yaitu penerapan metode peringatan dan pemberian motivasi terhadap peningkatan minat belajar peserta didik pada materi konsumsi, tabungan dan investasi.

\section{Penutup}

a.Peneliti melakukan pengamatan terhadap peserta didik yang berpotensi untuk melanjutkan sekolah dan menganalisis terhadap hasil penelitian.

b.Penelitian juga akan melakukan pengamatan terhadap peserta didik atas hasil angket yang dijawab.

\section{Pembahasan dan Hasil}

Berdasarkan penelitian yang dilakukan di Pon - Pes Muhammadiyah KHA.Dahlan Sipirok, maka penulis akan menguraikan temuan data sebagaimana yang diidentifikasi, penulis membuat kriteria pembobotan nilai sebagi berikut.

a. Pilihjawaban "a" ( Ya ) diber inilai 3

b. Pilihjawaban "b" ( Kadang-kadang ) diberi nilai 2

c. Pilihjawaban "c" ( Tidak )diberi nilai 1

Untuk mencari presentase jawaban angket responden digunakan rumus presentase sebagai berikut:

$$
\mathrm{P}=\frac{F}{N} x 100 \%
$$

Keterangan:

$\mathrm{P}$ : Presentase jawaban yang dijawab responden

F : Frekuensi yang dijawab responden terhadap opsi yang ditawarkan

$\mathrm{N}$ : Jumlah sampel 
Tabel 1

Apakah penggunaan

metode pembelajaran peringatan yang diterapkan pada mata pelajaran ekonomi dapat meningkatkan minat belajar anda ?

\begin{tabular}{|c|c|c|c|}
\hline No & $\begin{array}{c}\text { Alternative } \\
\text { Jawaban }\end{array}$ & $\mathbf{F}$ & $\begin{array}{c}\mathrm{P}= \\
\frac{f}{N} x 100 \%\end{array}$ \\
\hline 1 & $\mathrm{Ya}$ & 24 & 80 \\
\hline 2 & $\begin{array}{l}\text { Kadang- } \\
\text { kadang }\end{array}$ & 6 & 20 \\
\hline \multirow[t]{2}{*}{3} & Tidak & 0 & 0 \\
\hline & Jumlah & 30 & 100 \\
\hline
\end{tabular}

Dari jawaban diatas dapat disimpulkan bahwa minat peserta didik meningkat terhadap pelajaran ekonomi. Hal ini terlihat dari jawaban yang diberikan yaitu yang menjawab ya 24 orang $80 \%$, yang menjawab kadang-kadang 6 orang $20 \%$ dan yang menjawab tidak 0orang $0 \%$.

Tabel 2

Apakah dengan metode pembelajaran peringatan anda menjadi lebih percaya diri untuk belajar ?

\begin{tabular}{|c|c|c|c|}
\hline No & $\begin{array}{c}\text { Alternative } \\
\text { Jawaban }\end{array}$ & $\mathbf{F}$ & $\begin{array}{c}\mathbf{P}= \\
\frac{\boldsymbol{f}}{\boldsymbol{N}} \mathbf{1 0 0} \%\end{array}$ \\
\hline 1 & Ya & 22 & 73,3 \\
\hline 2 & $\begin{array}{c}\text { Kadang- } \\
\text { kadang }\end{array}$ & 8 & 26,7 \\
\hline 3 & $\begin{array}{c}\text { Tidak } \\
\text { Jumlah }\end{array}$ & $\mathbf{3 0}$ & $\mathbf{1 0 0}$ \\
\hline
\end{tabular}

Dari jawaban diatas dapat disimpulkan bahwa peserta didik lebih percaya diri untuk belajar ekonomi. Hal ini terlihat dari jawaban yang diberikan yaitu yang menjawab ya 22 orang $73,3 \%$, yang menjawab kadang-kadang 8 orang $26,7 \%$, dan yang menjawab tidak 0 orang $0 \%$.

Terdapat tiga variabel dalam penelitian ini yaitu variabel antara penerapan metode pembelajaran peringatan dan pemberian motivasi terhadap peningkatan minat belajar pada materi pokok konsumsi,tabungan dan investasi peserta didik .

Penelitian dilakukan beranjak dari masalah, ada rumusan masalah penelitianini adalah apakah dengan penerapan metode peringatan dan pemberian motivasidapat meningkatkan minat belajar pada materi pokok konsumsi, tabungan, dan investasi di kelas X Pon-Pes Muhammadiyah KHA. Dahlan Sipirok tahun pelajaran 2016/2017."’?

Setelah penulis melakukan peninjauan pustaka yaitu dengan membaca buku-buku dan teori -teori yang relevan dengan variabel penelitian, maka penulis menentukan penelitian yaitu : :"Apakah Dengan Penerapan Metode Peringatan Dan Pemberian Motivasi Dapat Meningkatkan Minat belajar Pada Materi Pokok Konsumsi, Tabungan, Dan Investasi Di Kelas X PonPes Muhammadiyah KHA. Dahlan Sipirok Tahun Pelajaran 2016/2017.’?

Berdasarkan penelitian diatas, maka penulis menyimpulkan bahwa hipotesis dapat diterima kebenarannya, Artinya "Ada peningkatan minat belajar dengan 
penerapan metode pembelajaran peringatan dan pemberian motivasi bidang studi ekonomi pada materi pokok konsumsi, tabungan dan investasi peserta didik di kelas $\mathrm{X}$ Pon-Pes Muhammadiyah KHA.Dahlan Sipirok Tahun Pelajaran 2016-2017."

\section{Kesimpulan}

Dari hasil penelitian dan analisis data yang diperoleh maka penulis menarik kesimpulan sebagai berikut:

1. Dilihat dari penerapan metode pembelajaran dan pemberian motivasi terhadap peningkatan minat belajar peserta didik kelas $\mathrm{X}$ Pon-Pes Muhammadiyah KHA.Dahlan Sipirok dikategorikan baik.

2. Data yang diperoleh dari tekhnik analisa data dengan menggunakan rumus " $r$ " product moment. Setelah dilakukan analisa hitung maka $\mathrm{r}$ hitungnya adalah 0,963 dengan melihat daftar tabel dengan jumlah $(\mathrm{N}=30)$ dengan taraf kesalahan 5\% adalah 0,361 dengan demikian dapat

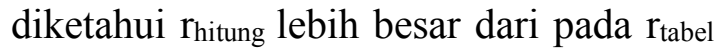
yaitu $0,963>0.361$ maka hipotesis alternative (Ha) dapat diterima.

3. Ada pengaruh yang signifikan antara penerapan metode pembelajaran peringatan dan pemberian motivasi terhadap peningkatan minat belajar bidang studi pada materi pokok konsumsi, tabungan dan investasi peserta didik di kelas X Pon-Pes Muhammadiyah KHA Dahlan Sipirok tahun Pelajaran 2016-2017.

\section{Saran}

Adapun saran-saran yang perlu peneliti kemukakan setelah melakukan penelitian ini adalah sebagai berikut:

1. Kepada para peserta didik diharapkan untuk lebih giat lagi belajar ekonomi dalam meningkatkan minat belajar yang lebih baik untuk masa depan.

2. Kepada guru hendaknya lebih memperhatikan dan memberikan motivasi kepada peserta didik agar lebih semangat dalam belajar serta peningkatan minatnya dalam belajar semakin baik

3. Kepada kepala sekolah selaku Pembina dalam organisasi sekolah, agar selalu memperhatikn, membimbing dan mengarahkan para guru dan peserta didik dalam upaya meningkatkan kualitas pendidikan kearah yang lebih baik.

4. Kepada rekan-rekan dan para peneliti yang ingin memperdalam penelitian tentang metode pembelajaran peringatan, pemberian motivasi dan peningkatan minat belajar agar dilihat dari sisi lain, sehingga minat belajar bidang studi ekonomi pada materi pokok konsumsi, tabungan dan investasi peserta didik semakin meningkat.

\section{Daftar Pustaka}

Anurrahman. 2012. Belajar dan Pembelajaran. Bandung:Alfabeta.

Briggson Martin.2006.Metode Penelitian.Surabaya:Sinar Maju

Dantes. Nyoman. 2012. Metode Penelitian. Yogyakarta:CV. Andi Offeset. 
Djamarah. Syaiful. Bahri. 2020.

Psikologi Belajar. Jakarta:Rineka. Cipta.

Fathoni. Abdurrahmat. 2006. Metodologi Penelitian Dan Tekhnik Penyusunan Skripsi.Jakarta:PT. Rineka. Cipta

Hamalik. Oemar. 2005. Strategi Belajar Mengajar. Bandung:Bandar. Madju.

Hamidi. 2007. Metodologi Penelitian. Surabaya: Al-Ikhlas.

Hidayat.Syafaruddin.Sedamayati. 2007. Metodologi Penelitian:SinarMadju.

Heri.2005Metode Penelitian .Jakarta:PT.Rineka Cipta.

Istarani. 2010. Metode Penelitian. Medan:Media Persada.

Kartono.2006.Metdologi

Peneitian.Tangerang:PT.Rineka Cipta.

MaslowAbraham.2006.Ekonomi.Sura baya:Yudhistira.

Nazir.Moh.2005. Metode Penelitian Suatu Pengantar.Jakarta:Rineka Cipta.

Notohadiprawiro. 2006. Metodologi Penelitian Bandung:PT.Remaja Rosdakarya.

Ngalim.Purwanto. 2005. Administrasi Dan Supervisi Pendidikan. Bandung:PT. Remaja Rosdakarya.

Ramayulis. 2007. Metode Penelitian. Bandung:Bandar Madju.

Riduwan.Metode Penelitian.Jakarta:G ramedia. 